\title{
Effect of Curtailed Shear Wall on Storey Drift of High Rise Buildings Subjected To Seismic Loads
}

\author{
U. L. Salve ${ }^{1}$ and R. S. Londhe ${ }^{2}$ \\ ${ }^{I}$ P. G. Student, M. E. Structural Engg., Govt. Engg. college, Aurangabad. \\ ${ }^{2}$ Associate Professor, Department of Applied Mechanics, Govt, Engg. college, Aurangabad.
}

\begin{abstract}
Shear wall is a structural element used to resist horizontal forces parallel to the plane of the wall. Shear wall has highly in plane stiffness and strength which can be used to simultaneously resist large horizontal loads and support gravity loads. Shear Walls are specially designed structural walls include in the buildings to resist horizontal forces that are induces in the plane of the wall due to wind, earthquake and other forces. To bring the maximum drift down to allowable limits, cross sectional dimensions of beams and columns have to be increased in many cases. For the study, two Symmetrical Structures of 15-storey and 21-storey are analyzed by using standard software package STAAD.Pro V8i. The parameters considered for the analysis are Shear wall, No. of Storey's, No. of bays (x, z), bay Width.

The main objectives of this study are

1. To compute the seismic response of reinforced concrete frame structures with curtailed shear walls.

2. To determine parameters like storey drift, storey shear and Lateral displacement.
\end{abstract}

Keywords: Shear Wall, Storey Drift, Lateral Displacement

\section{Introduction}

RC multi-storey buildings are adequate for resisting both the vertical and horizontal load. When such building is designed without shear wall, beam and column sizes are quite heavy and there is problem arises at these joint and it is congested to place and vibrate concrete at these places and displacement is quite heavy which induces heavy forces in building member. Shear wall may become essential from the point of view of economy and control of horizontal displacement.

These walls generally start at foundation level and are continuous throughout the building height. Shear walls are a type of structural system that provides lateral resistance to a building or structure. Shear walls are like vertically-oriented wide beams that carry earthquake loads downwards to the foundation.

\section{Selection Of Various Parameters}

For the study, two Symmetrical Structures 15-Storey and 21-Storey are analyzed by using standard software package STAAD.Pro V8i. The total plan dimension of building is $18.5 \mathrm{~m} \times 18.5 \mathrm{~m}$.

The parameters considered for the analysis are

1. Shear Wall

2. No. of Storey's

3. No. of Bays (x, $\mathrm{z})$

4. Bay Width $(\mathrm{x}, \mathrm{z})$

\section{Description of models}

The designation used for the building models is as given in following Table 1.

Table 1. Description of building model

\begin{tabular}{|c|c|c|}
\hline Model No. & Type of Structure & Designation \\
\hline 1 & G+15 Storey RCC Structure without Shear Wall & G15WSW \\
\hline 2 & G+15 Storey RCC Structure with Full Shear Wall & G15FSW \\
\hline 3 & G+15 Storey RCC Structure with Shear Wall up to $14^{\text {th }}$ floor & G15SW14 \\
\hline 4 & G+15 Storey RCC Structure with Shear Wall up to $13^{\text {th }}$ floor & G15SW13 \\
\hline 5 & G+15 Storey RCC Structure with Shear Wall up to $12^{\text {th }}$ floor & G15SW12 \\
\hline 6 & G+15 Storey RCC Structure with Shear Wall up to $11^{\text {th }}$ floor & G15SW11 \\
\hline 7 & G+15 Storey RCC Structure with Shear Wall up to $10^{\text {th }}$ floor & G15SW10 \\
\hline 8 & G+15 Storey RCC Structure with Shear Wall up to $09^{\text {th }}$ floor & G15SW09 \\
\hline 9 & G+21 Storey RCC Structure without Shear Wall & G21WSW \\
\hline 10 & G+21 Storey RCC Structure with Full Shear Wall & G21FSW \\
\hline 11 & G+21 Storey RCC Structure with Shear Wall up to $20^{\text {th }}$ floor & G21SW20 \\
\hline 12 & G+21 Storey RCC Structure with Shear Wall up to $19^{\text {th }}$ floor & G21SW19 \\
\hline 13 & G+21 Storey RCC Structure with Shear Wall up to $18^{\text {th }}$ floor & G21SW18 \\
\hline
\end{tabular}




\begin{tabular}{|l|l|l|}
\hline 14 & G+21 Storey RCC Structure with Shear Wall up to $17^{\text {th }}$ floor & G21SW17 \\
\hline 15 & G+21 Storey RCC Structure with Shear Wall up to $16^{\text {th }}$ floor & G21SW16 \\
\hline 16 & G+21 Storey RCC Structure with Shear Wall up to $15^{\text {th }}$ floor & G21SW15 \\
\hline 17 & G+21 Storey RCC Structure with Shear Wall up to $14^{\text {th }}$ floor & G21SW14 \\
\hline
\end{tabular}

\section{Dimensions Of Proposed Model}

Plan dimension of structure $=18.5 \mathrm{~m} \times 18.5 \mathrm{~m}$

No of bays in X-direction $=5$

No of bays in Y-direction $=5$

Spacing of bays in X-direction $=4.5 \mathrm{~m}$

Spacing of bays in Y-direction $=4.5 \mathrm{~m}$

Height of all typical floors (including ground floor) $=3.0 \mathrm{~m}$

Height of parapet wall $=1 \mathrm{~m}$ (all around the periphery of roof floor)

\section{General Characteristics Of The Analyzed Structural Systems}

The general characteristics of the structure are as per Table2. Which is given below.

Table 2. General Characteristics of the Analyzed Structural Systems

\begin{tabular}{|l|c|c|c|}
\hline \multirow{2}{*}{ Type of Structural system } & \multicolumn{3}{|c|}{ Column Groups for all Models } \\
\cline { 2 - 4 } & $\begin{array}{c}\text { C1 (Corner } \\
\text { Columns) }\end{array}$ & C2 (External Columns) & C3 (Internal Columns) \\
\hline Slab $(\mathrm{mm})$ & 150 & 150 & 150 \\
\hline Column $(\mathrm{mm})$ & 700 X 700 & 850 X 700 & 1000 X 700 \\
\hline Beam $(\mathrm{mm})$ & \multicolumn{3}{|c|}{ For Concrete M25 and For Steel Fe 415 } \\
\hline Thickness of Shear Wall $(\mathrm{mm})$ & \multicolumn{3}{|c|}{3} \\
\hline Material Properties & \multicolumn{3}{|c|}{25} \\
\hline Height of each floor $(\mathrm{m})$ & \multicolumn{3}{|c|}{} \\
\hline Density $\left(\mathrm{kN} / \mathrm{m}^{2}\right)$ & \multicolumn{3}{|c|}{} \\
\hline
\end{tabular}

\section{Results and Discussion}

The seismic analysis of all the models that includes full and varying height of shear walls has been done by using standard software package STAAD.Pro V8i and the results are shown below. The parameters which are to be studied are lateral displacement, storey drift, axial force, shear force and bending moments.

Table 3. Lateral displacement of 15- Storey Structure with all column groups

\begin{tabular}{|c|c|c|c|c|c|c|}
\hline \multirow{2}{*}{$\begin{array}{c}\text { MODEL } \\
\text { NAME }\end{array}$} & \multicolumn{2}{|c|}{ C1 } & \multicolumn{2}{c|}{ C2 } & \multicolumn{2}{c|}{ C3 } \\
\cline { 2 - 7 } & $\begin{array}{c}\text { MAX. } \\
\text { DISPLCEENT } \\
(\mathbf{m m})\end{array}$ & $\begin{array}{c}\text { STORE } \\
\text { Y DRIFT } \\
(\mathbf{m m})\end{array}$ & $\begin{array}{c}\text { MAX. } \\
\text { DISPLACEMEN } \\
\text { T (mm) }\end{array}$ & $\begin{array}{c}\text { STOREY } \\
\text { DRIFT } \\
(\mathbf{m m})\end{array}$ & $\begin{array}{c}\text { MAX. } \\
\text { DISPLACEMENT } \\
(\mathbf{m m})\end{array}$ & $\begin{array}{c}\text { STOREY } \\
\text { DRIFT (mm) }\end{array}$ \\
\hline G15WSW & 159.542 & - & 162.682 & - & 162.617 & \\
\hline G15FSW & 142.934 & 0.3380 & 142.877 & 0.3380 & 141.198 & 0.1710 \\
\hline G15SW14 & 142.596 & 0.0230 & 142.539 & 0.0230 & 141.027 & 0.1140 \\
\hline G15SW13 & 142.573 & 0.0500 & 142.516 & 0.0500 & 140.913 & 0.1240 \\
\hline G15SW12 & 142.523 & 0.0620 & 142.466 & 0.0620 & 140.789 & 0.0810 \\
\hline G15SW11 & 142.461 & 0.0110 & 142.404 & 0.0110 & 140.708 & -0.0570 \\
\hline G15SW10 & 142.450 & -0.1200 & 142.393 & -0.1190 & 140.765 & -0.2820 \\
\hline G15SW09 & 142.570 & 0.0000 & 142.512 & 0.0000 & 141.047 & 0.0000 \\
\hline
\end{tabular}




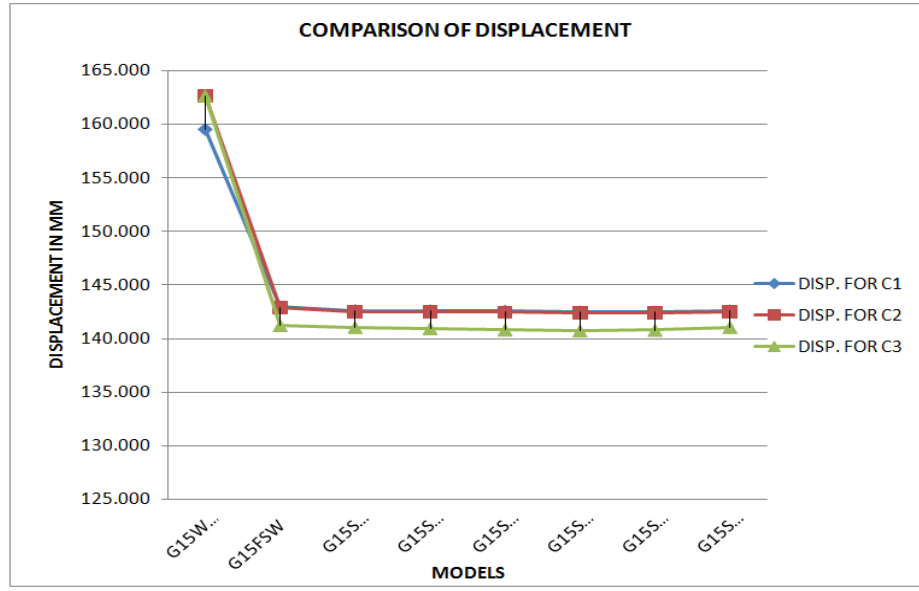

Fig.1. Comparison of Lateral displacement 15 Storey Structure with all column groups

Table 4. Lateral displacement of 21- Storey Structure with all column groups

\begin{tabular}{|c|c|c|c|c|c|c|}
\hline \multirow[b]{2}{*}{$\begin{array}{l}\text { MODEL } \\
\text { NAME }\end{array}$} & \multicolumn{2}{|c|}{ C1 } & \multicolumn{2}{|l|}{$\mathrm{C2}$} & \multicolumn{2}{|l|}{$\mathrm{C3}$} \\
\hline & $\begin{array}{c}\text { MAX. } \\
\text { DISPLACEMENT } \\
(\mathrm{mm})\end{array}$ & $\begin{array}{c}\text { STOREY } \\
\text { DRIFT }(\mathbf{m m})\end{array}$ & $\begin{array}{c}\text { MAX. } \\
\text { DISPLACEMENT } \\
(\mathrm{mm})\end{array}$ & $\begin{array}{c}\text { STOREY } \\
\text { DRIFT } \\
(\mathrm{mm})\end{array}$ & $\begin{array}{l}\text { MAX. DISPLACEMENT } \\
(\mathbf{m m})\end{array}$ & $\begin{array}{c}\text { STOREY } \\
\text { DRIFT }(\mathbf{m m})\end{array}$ \\
\hline G21WSW & 294.384 & 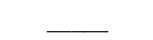 & 262.188 & 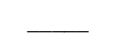 & 262.118 & 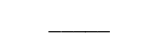 \\
\hline G21FSW & 237.120 & 0.1330 & 237.056 & 0.1330 & 235.495 & 0.2170 \\
\hline G21SW20 & 236.987 & 0.0320 & 236.923 & 0.0320 & 235.278 & 0.1240 \\
\hline G21SW19 & 236.955 & 0.0480 & 236.891 & 0.0070 & 235.154 & 0.0067 \\
\hline G21SW18 & 236.907 & 0.0950 & 236.884 & 0.1360 & 234.954 & 0.1540 \\
\hline G21SW17 & 236.812 & 0.1200 & 236.748 & 0.1200 & 234.800 & 0.1760 \\
\hline G21SW16 & 236.692 & 0.1050 & 236.628 & 0.1040 & 234.624 & 0.1060 \\
\hline G21SW15 & 236.587 & -0.0510 & 236.524 & -0.1500 & 234.518 & -0.0060 \\
\hline G21SW14 & 236.638 & 0.0000 & 236.674 & 0.0000 & 234.524 & 0.0000 \\
\hline
\end{tabular}

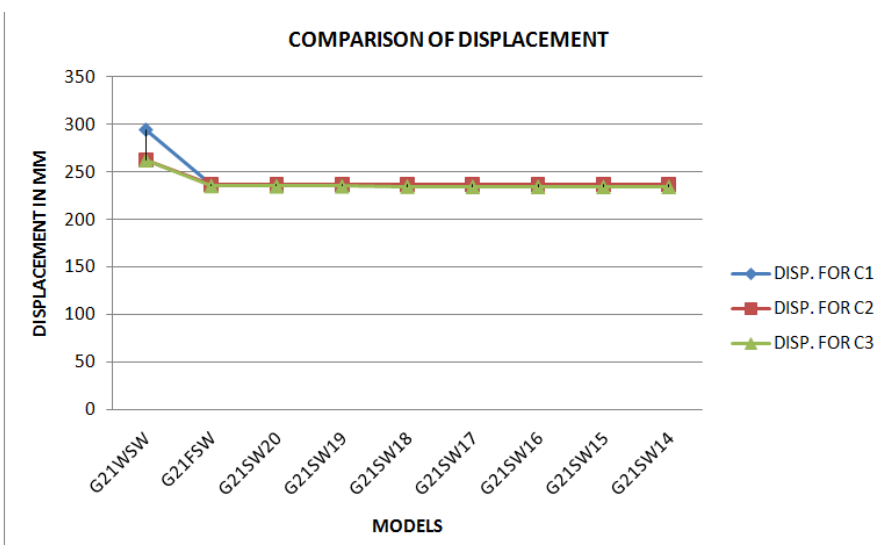

Fig. 2. Comparison of Lateral displacement 21-Storey Structure with all column groups

Table 5. Comparative statement of 15-Storey and 21 Storey models for Lateral Displacement A. Displacement of 15 -Storey model

\begin{tabular}{|c|c|c|c|c|c|c|}
\hline \multirow{2}{*}{ Model } & \multicolumn{2}{|c|}{ C1 } & \multicolumn{2}{|c|}{ C2 } & \multicolumn{2}{c|}{ C3 } \\
\cline { 2 - 4 } & DISP.(mm) & $\begin{array}{c}\text { STOREY DRIFT } \\
(\mathrm{mm})\end{array}$ & DISP.(mm) & $\begin{array}{c}\text { STOREY } \\
\text { DRIFT (mm) }\end{array}$ & DISP.(mm) & $\begin{array}{c}\text { STOREY } \\
\text { DRIFT (mm) }\end{array}$ \\
\hline G15FSW & 142.934 & \multirow{2}{*}{0.484} & 142.877 & 0.484 & 141.198 & 0.433 \\
\hline G15SW10 & 142.450 & 142.393 & 140.765 & 0.43 \\
\hline
\end{tabular}

From the result presented in Table 5 (A). The displacement for model G15FSW is 142.934 and for the model G15SW10 is 142.450 for Column group C1 so the increase in the displacement with full height of shear wall and varying height is only $0.5 \%$ and is same for the column group C2 and C3. 
The storey drift as per IS 1893:2002 shall not exceed 0.004 times the storey height i.e. 0.004 X 3000= $12 \mathrm{~mm}$. So storey drift from above comparison is $0.484 \mathrm{~mm}$ which is satisfying the IS recommendation.

B. Displacement of 21-Storey model

\begin{tabular}{|c|c|c|c|c|c|c|}
\hline \multirow{2}{*}{ Model } & \multicolumn{2}{|c|}{ C1 } & \multicolumn{2}{|c|}{ C2 } & \multicolumn{2}{c|}{ C3 } \\
\cline { 2 - 6 } & DISP.(mm) & $\begin{array}{c}\text { STOREY DRIFT } \\
(\mathrm{mm})\end{array}$ & DISP.(mm) & $\begin{array}{c}\text { STOREY } \\
\text { DRIFT (mm) }\end{array}$ & DISP.(mm) & $\begin{array}{c}\text { STOREY } \\
\text { DRIFT (mm) }\end{array}$ \\
\hline G21FSW & 237.120 & \multirow{2}{*}{0.533} & 237.056 & 0.532 & 235.495 & \multirow{2}{*}{0.977} \\
& & 236.587 & 236.524 & 234.518 & \\
\hline
\end{tabular}

From the result presented in Table 5 (B). The displacement for model G21FSW is 237.120 and for the model G21SW15 is 236.587 for Column group C1 so the increase in the displacement with full height of shear wall and varying height is only $0.5 \%$ and is same for the column group C2 and C3.

The storey drift as per IS 1893:2002 shall not exceed 0.004 times the storey height i.e. $0.004 \times 3000=$ $12 \mathrm{~mm}$. So storey drift from above comparison is $0.533 \mathrm{~mm}$ which is satisfying the IS recommendation.

Table 6. Comparative statement of 15-Storey and 21 Storey models for Axial Force

A. Axial Force of 15 -Storey model

\begin{tabular}{|c|c|c|c|}
\hline Model & C1 & C2 & C3 \\
\hline G15FSW & 4450 & 5800 & 10530 \\
\hline G15SW10 & 4450 & 5790 & 10600 \\
\hline
\end{tabular}

B. Axial Force of 21-Storey model

\begin{tabular}{|c|c|c|c|}
\hline Model & C1 & C2 & C3 \\
\hline G21FSW & 6340 & 8100 & 13000 \\
\hline G21SW15 & 6340 & 8090 & 13000 \\
\hline
\end{tabular}

Table 7. Comparative statement of 15-Storey and 21 Storey models for Shear Force

A. Shear Force of 15-Storey model

\begin{tabular}{|c|c|c|c|c|c|c|}
\hline \multirow{2}{*}{ Model } & \multicolumn{2}{|c|}{ C1 } & \multicolumn{2}{c|}{ C2 } & \multicolumn{2}{c|}{ C3 } \\
\cline { 2 - 7 } & Fy & Fz & Fy & Fz & Fy & Fz \\
\hline G15FSW & 91.330 & 95.368 & 168.362 & 152.515 & 263.886 & 154.483 \\
\hline G15SW10 & 91.083 & 95.255 & 167.976 & 152.530 & 262.566 & 163.013 \\
\hline
\end{tabular}

B. Shear Force of 21-Storey model

\begin{tabular}{|c|c|c|c|c|c|c|}
\hline \multirow{2}{*}{ Model } & \multicolumn{2}{|c|}{ C1 } & \multicolumn{2}{|c|}{ C2 } & \multicolumn{2}{c|}{ C3 } \\
\cline { 2 - 7 } & Fy & Fz & Fy & Fz & Fy & Fz \\
\hline G21FSW & 97.522 & 102.357 & 186.162 & 172.380 & 297.371 & 183.752 \\
\hline G21SW15 & 97.428 & 102.256 & 186.119 & 172.501 & 295.450 & 183.566 \\
\hline
\end{tabular}

Table 8. Comparative statement of 15-Storey and 21 Storey models for Bending Moments

A. Bending Moments of 15-Storey model

\begin{tabular}{|c|c|c|c|c|c|c|}
\hline \multirow{2}{*}{ Model } & \multicolumn{2}{|c|}{ C1 } & \multicolumn{2}{|c|}{ C2 } & \multicolumn{2}{c|}{ C3 } \\
\cline { 2 - 7 } & My & $\mathrm{Mz}$ & $\mathrm{My}$ & $\mathrm{Mz}$ & 469.882 & 834.425 \\
\hline G15FSW & 372.424 & 362.273 & 466.803 & 640.118 & 471.750 & 832.117 \\
\hline G15SW10 & 374.253 & 361.119 & 469.123 & 638.043 & 4 \\
\hline
\end{tabular}

B. Bending Moments of 21-Storey model

\begin{tabular}{|c|c|c|c|c|c|c|}
\hline \multirow{2}{*}{ Model } & \multicolumn{2}{|c|}{ C1 } & \multicolumn{2}{c|}{ C2 } & \multicolumn{2}{c|}{ C3 } \\
\cline { 2 - 7 } & My & Mz & My & Mz & My & 917.052 \\
\hline G21FSW & 408.201 & 395.453 & 512.105 & 699.795 & 519.429 & 915.154 \\
\hline G21SW15 & 409.145 & 394.999 & 513.295 & 698.988 & 519.341 & \\
\hline
\end{tabular}

From the result presented in Table 6, 7 and 8 there is no significant increase in the values of Axial force, Shear force and Bending moments for all the column groups since the shear wall is decreased up to considerable floors. 


\section{Conclusion}

Following conclusions are drawn based on the experimental results.

I. As far as lateral displacement is concerned there is no there is significant increase in the value of lateral displacement.

II. The total increase in the value of Lateral displacement is only $0.5 \%$ for full height of shear wall and varying height of shear wall.

III. The storey drift as per IS 1893:2002 shall not exceed 0.004 times the storey height. i.e. 0.004 X $3000=$ $12 \mathrm{~mm}$ which is also satisfied.

IV. There is no significant increase in the values of axial force, Shear force and bending moments for all the column groups since the shear wall is decreased up to considerable floors.

V. Shear wall can be used up to $60 \%$ of total height of the structure without reduction of lateral loads and hence reduction in concrete cost also.

\section{References}

[1]. Indian Standard Criteria For Earthquake Resistant Design Of Structures Part 1 ( Fijth Revision ) IS 1893( Part 1 ) :2002 Bureau of India Standard, New Delhi.

[2]. Mir M. Ali, Kyoung Sun Moon. "Structural developments in tall buildings: current trends and future prospects". Architectural Science Review (September 2007). Retrieved 2008-12-10

[3]. Goel, R.K. (2007). "Evaluation of Current Nonlinear Static Procedures Using Strong Motion Records, "Proceedings of the 2007 Structures Congress, Long Beach, CA, American Society of Civil Engineers, Reston, VA.

[4]. Jayachandran P. and Browne, M.S., (1995), "Approximate Methods of Analysis of Tall Framed-Tube Buildings", Proceedings, International Conference on Structural Systems and Stability, PSG College of Technology, Coimbatore, India, July.

[5]. Md. Mahmud Sazzad and Md. Kamruzzaman, "Drift control of tall building frames", Journal of Civil Engineering, The institution of Engineers, Bangladesh, Vol.CE21, No.4

[6]. Khan F.R. (1973). "Evolution of structural systems for high-rise buildings in steel and concrete", Proceedings of the 10th Regional Conference on Tall Buildings-Planning, Design and Construction. Bratislava: Czechoslovak Scientific and Technical Association.

[7]. Jinkoo Kim and Young-Ho Lee "Seismic performance evaluation of diagrid system buildings", The Structural Design of Tall and Special Buildings Published Online 2010.

[8]. Q.S. Li, "Seismic Random vibration analysis of tall building", Engineering structures 26(2004).

[9]. Ker-Chun Lin, Chu-Chieh J. Lin, Jung-Yu Chen, Heui-Yung Chang, "Seismic reliability of steel framed buildings “, Elsevier ,32 (2010) 174-182

[10]. Y.L. Xu , Q. He, J.M. Ko , "Dynamic response of damper-connected adjacent buildings under earthquake excitation", Engineering Structures 21 (1999) 135-148

[11]. Umesh. N. Karadi and Shahzad Jamil Sardar, "effect of change in shear wall Location on storey drift of Multistorey building subjected To lateral loads", ISSN: 2319-8753

[12]. Xiao-Kang Zou, Chun-Man Chan, "An optimal resizing technique for seismic drift design of concrete buildings subjected to response spectrum and time history loadings", Computers and Structures 83 (2005) 1689-1704.

[13]. Chun-Man Chan And Qian Wang, "Optimal Drift Design Of Tall Reinforced Concrete Buildings With Non-Linear Cracking Effects”, Struct. Design Tall Spec. Build. 14, 331-351 (2005)

[14]. Siamak Epackachi1, Rasoul Mirghaderi, Omid Esmaili, Ali Asghar Taheri Behbahani and Shahram Vahdani, "Seismic evaluation of a 56-storey residential reinforced concrete high-rise building based on nonlinear dynamic time-history analyses", Struct. Design Tall Spec. Build. (2010)

[15]. Pedro A. Hidalgo, Christian A. Ledezma,and Rodrigo M. Jordana), "Seismic Behavior of Squat Reinforced Concrete Shear Walls" , DOI: $10.1193 / 1.1490353$.

[16]. Potty N. S., "Practical Modelling Aspects for Analysis of Shear Walls Using Finite Element Method", ICCBT 2008 - C - (08) pp89-98.

[17]. Masato SAKURAI, Hiroshi KURAMOTO, Tomoya MATSUI and Tomofusa AKITA, "Seismic Performance Of RC Shear Walls With Multi-Openings", October 12-17, 2008 